\title{
Pengaruh Produk Domestik Bruto (PDB), Jumlah Bagi Hasil dan Jumlah Kantor terhadap Jumlah Deposito Muḍārabah Bank Syariah di Indonesia Periode 2011-2015
}

\author{
Dita Meyliana \\ UIN Syarif Hidayatullah Jakarta \\ email: ditameyliana16@gmail.com
}

\author{
Ade Sofyan Mulazid \\ UIN Syarif Hidayatullah Jakarta \\ email: adesofyanmulazid@uinjkt.ac.id
}

\begin{abstract}
This study found the influence of Gross Domestic Product (GDP), the amount of profit sharing and the number of offices to the number of mudarrabah deposits of Islamic banks in Indonesia. The data used in this research is quarterly data from 2011-2015 period. The method of analysis used in this research is Data Panel Regression Analysis by using computer program Eviews version 9.0 and Microsoft Excel 2010. The results in this study indicate that partially Gross Domestic Product (GDP), the amount of profit sharing and the number of offices have a significant influence on the amount Muḍarabah deposits. This result is evidenced by a significant value of 0.0000 that is smaller than 0.05 and has a positive direction. So the greater of GDP, number of profit sharing and the number of offices, the greater number of mudārabah deposits of Islamic banks in Indonesia.
\end{abstract}

Keywords: Gross Domestic Product (GDP); Profit Sharing; Number of Offices and Number of Muḍärabah Deposits.

Abstrak: Penelitian ini menemukan adanya pengaruh Produk Domestik Bruto (PDB), jumlah bagi hasil dan jumlah kantor terhadap jumlah deposito muḍārabah bank syariah di Indonesia. Data yang digunakan dalam penelitian ini adalah data triwulan periode 2011-2015. Metode analisis yang digunakan dalam penelitian ini adalah Analisis Regresi Data Panel dengan menggunakan program komputer Eviews versi9.0 dan Microsoft Excel 2010. Hasil dalam penelitian ini menunjukkan bahwa secara parsial Produk Domestik Bruto (PDB), jumlah bagi hasil dan jumlah kantor memiliki pengaruh signifikan terhadap jumlah deposito muḍärabah. Hasil ini dibuktikan dengan nilai signifikan sebesar 0.0000 yaitu lebih kecil dari 0.05 dan memiliki arah positif. Sehingga semakin besar PDB, jumlah bagi hasil dan jumlah kantor, maka semakin besar pula jumlah deposito muḍārabah bank syariah di Indonesia.

Kata Kunci: Produk Domestik Bruto (PDB); Jumlah Bagi Hasil; Jumlah Kantor dan Jumlah Deposito Muḍārabah. 


\section{Pendahuluan}

Perbankan syariah mengalami perkembangan yang cukup pesat, terutama dalam beberapa tahun terakhir. Hal ini, dibuktikan dengan adanya peningkatan baik dari segi aset, pembiayaan yang diberikan maupun dana pihak ketiga yang dihimpun dari masyarakat. Peningkatan tersebut dapat dilihat pada tabel di bawah ini:

Tabel 1. Perkembangan Aset, PYD dan DPK Bank Syariah di Indonesia

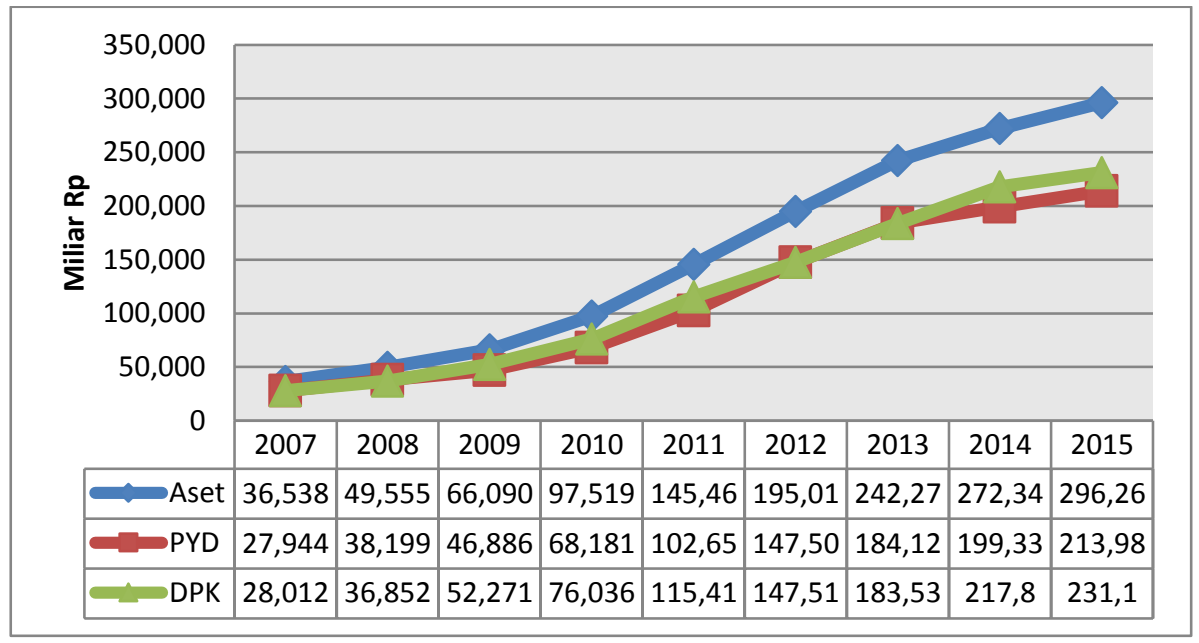

Sumber: Statistik Perbankan Syariah, Otoritas Jasa Keuangan.

Berdasarkan tabel di atas, dapat dilihat bahwa aset dana pihak ketiga dan pembiayaan yang diberikan bank syariah meningkat setiap tahunnya. Namun, selain perkembangan yang dialami dari tahun ke tahun, terdapat pula beberapa permasalahan dan tantangan yang harus dihadapi oleh bank syariah di Indonesia. Agustianto (2016) mengungkapkan bahwa setidaknya ada beberapa masalah yang menjadi kendala berkembangnya bank syariah di Indonesia, yaitu keterbatasan modal, sumber dana serta SDM maupun TI yang belum mumpuni. 
Persoalan terbesar adalah masalah sumber dana menjadi perhatian penting bagi bank syariah karena lembaga keuangan bersaing dalam mengumpulkan sumber dana terutama dana yang berasal dari masyarakat. Sesungguhnya persaingan dalam mengumpulkan dana tersebut, tidak hanya terjadi antara bank syariah dan bank konvensional. Persaingan terjadi pula antarlembaga perbankan dengan lembaga keuangan non-bank.

Kenaikan tingkat bunga bank konvensional menyebabkan daya tarik masyarakat untuk menyimpan dana di bank konvensional dan menurunnya minat masyarakat dalam menyimpan dana di bank syariah. Dana yang dihimpun oleh bank syariah dari masyarakat menurun dan pembiayaan yang disalurkan mengalami peningkatan. Meningkatnya dana keluar yang tidak diimbangi dengan bertambahnya sumber dana akan meningkatkan risiko likuditas bank syariah (Sudarsono 2009).

Sumber dana yang berasal dari masyarakat atau dana pihak ketiga merupakan sumber dana penting bagi operasional bank syariah. Selain itu, sumber dana yang berasal dari masyarakat juga menjadi tolok-ukur tingkat kepercayaan masyarakat terhadap bank syariah. Oleh sebab itu, bank syariah selalu mengupayakan untuk meningkatkan dana pihak ketiganya yang diperoleh dari masyarakat.

Berdasarkan komposisi dana pihak ketiga yang diterima oleh bank syariah, deposito menjadi produk yang memiliki porsi paling besar dibandingkan giro dan tabungan. Hal ini, menunjukkan bahwa masyarakat lebih memilih menempatkan dananya dalam bentuk deposito muḍārabah dibandingkan produk simpanan lainnya. Tingginya minat masyarakat ini dapat dipahami karena umumnya, bank syariah memberikan tingkat bagi hasil yang lebih tinggi pada produk deposito muḍārabah dibandingkan simpanan dalam bentuk lain. 
Tabel 2. Persentase Pertumbuhan Deposito Mudārabah Bank Syariah di Indonesia (2010-2015)

\begin{tabular}{ccc}
\hline Tahun & $\begin{array}{c}\text { Deposito Muḍārabah } \\
\text { Miliar Rp }\end{array}$ & $\begin{array}{c}\text { Pertumbuhan } \\
\%\end{array}$ \\
\hline 2010 & 44,072 & - \\
2011 & 70,806 & 60.65 \\
2012 & 84,732 & 19.67 \\
2013 & 107,812 & 27.24 \\
2014 & 135,628 & 25.80 \\
2015 & 141,329 & 4.20 \\
\hline
\end{tabular}

Sumber: Statistik Perbankan Syariah, Otoritas Jasa Keuangan, 2015.

Berdasarkan tabel 2, deposito mudārabah pada bank syariah di Indonesia mengalami pertumbuhan setiap tahunnya. Namun pada tahun 2015, pertumbuhan deposito muḍärabah tidak sebesar tahun-tahun sebelumnya. Besarnya jumlah deposito pada bank syariah sangat bergantung pada faktor-faktor internal maupun eksternal, serta fenomena yang terjadi pada perekonomian di Indonesia.

Menurut Kasri dan Kassim, bagi hasil memiliki pengaruh terhadap deposito muḍārabah (Kasri 2009). Besarnya nominal deposito muḍārabah bank syariah sangat bergantung pada peran masyarakat sebagai deposan. Mengingat sebagian besar nasabah bank syariah juga merupakan nasabah bank konvensional, mereka cenderung memilih menempatkan dananya pada produk simpanan yang memberikan return yang lebih tinggi. Dengan demikian, faktor bagi hasil sebagai return dari investasi yang dilakukan menjadi faktor yang sangat penting sebelum menempatkan dananya dalam produk deposito muḍārabah.

Menurut Hilman, PDB juga berpengaruh terhadap jumlah deposito muḍārabah bank syariah (Hilman 2016). Hal ini, disebabkan karena tabungan merupakan sisa pendapatan yang tidak dibelanjakan oleh konsumen. Semakin besar jumlah pendapatan yang diterima oleh suatu masyarakat, 
maka semakin besar pula jumlah tabungan yang akan dilakukan olehnya. PDB sebagai salah satu indikator tingkat pendapatan masyarakat ikut memengaruhi jumlah deposito mud̄ārabah bank syariah.

Di samping faktor tingkat return dan pendapatan, menurut Yudho jumlah kantor juga memengaruhi jumlah deposito mudārabah bank syariah di Indonesia (Yudho 2010). Jumlah kantor merupakan salah satu faktor pelayanan yang diberikan oleh bank syariah kepada masyarakat. Meningkatnya jumlah kantor bank syariah akan memudahkan masyarakat menempatkan dananya pada bank syariah terutama dalam produk deposito muḍärabah. Meningkatnya jumlah kantor juga membuka kesempatan besar bagi bank syariah untuk menghimpun dana dari masyarakat. Penelitian ini berbeda dengan penelitian sebelumnya, yakni ingin mengetahui sejauhmana pengaruh PDB terhadap jumlah deposito muḍārabah, sehingga penelitian ini diharapkan dapat melengkapi penelitian sebelumnya.

Berdasarkan rumusan masalah di atas, tujuan dari penelitian ini adalah: (1) menganalisis pengaruh Produk Domestik Bruto (PDB) terhadap jumlah deposito muḍārabah, (2) menganalisis pengaruh jumlah bagi hasil terhadap jumlah deposito muḍārabah, dan (3) menganalisis pengaruh jumlah kantor terhadap jumlah deposito muḍārabah.

\section{Landasan Teori}

\section{Bank Syariah}

Bank syariah adalah badan usaha yang fungsinya sebagai penghimpun dana dari masyarakat dan penyalur dana kepada masyarakat yang sistem dan mekanisme kegiatan usahanya berdasarkan hukum Islam sebagaimana yang diatur dalam al-Qur'an dan al-Hadis. Sedangkan dalam kamus perbankan, yang dimaksud dengan bank syariah adalah bank yang menggunakan sistem dan operasi perbankan berdasarkan prinsip syariah Islam, yaitu mengikuti 
tata cara berusaha dan perjanjian berusaha yang ditentukan oleh al-Qur'an dan al-Hadis (Sadi 2015).

Bank syariah didirikan dengan tujuan untuk mempromosikan dan mengembangkan penerapan prinsip-prinsip Islam, syariah dan tradisinya ke dalam transaksi keuangan dan perbankan serta bisnis yang terkait. Prinsip utama yang diikuti oleh bank syariah adalah sebagai berikut (Arifin 2009): (1) Larangan riba dalam berbagai bentuk transaksi, (2) Melakukan kegiatan usaha dan perdagangan berdasarkan perolehan keuntungan yang sah, dan (3) Memberikan zakat.

\section{Muḍārabah}

Mudārabah adalah bentuk kontrak antara dua pihak atau lebih, di mana satu pihak berperan sebagai pemilik modal dan mempercayakan sejumlah modalnya untuk dikelola dengan tujuan untuk mendapatkan untung (Karim 2009). Muḍārabah adalah akad kerja sama usaha antara dua pihak, di mana pihak pertama (șahib al-māl) menyediakan seluruh (100\%) modal sedangkan pihak lainnya menjadi pengelola. Keuntungan usaha secara muḍārabah dibagi menurut kesepakatan yang dituangkan dalam kontrak, sedangkan apabila rugi ditanggung oleh pemilik modal selama kerugian itu bukan akibat kelalaian si pengelola. Seandainya kerugian itu diakibatkan karena kecurangan atau kelalaian si pengelola, si pengelola harus bertanggung jawab atas kerugian tersebut (Antonio 2001).

Muḍārabah biasanya diterapkan pada produk-produk pembiayaan dan pendanaan. Pada sisi penghimpunan dana, mud̄ōrabah diterapkan pada: (1) Tabungan berjangka, yaitu tabungan yang dimaksudkan untuk tujuan khusus, seperti tabungan haji, tabungan kurban, dan sebagainya; dan (2) Deposito spesial (special investment), di mana dana yang dititipkan nasabah khusus untuk bisnis tertentu, misalnya muräbaḥah saja atau ijārah saja.

Adapun pada sisi pembiayaan, muḍārabah diterapkan untuk: (1) Pembiayaan modal kerja, seperti modal kerja perdagangan dan jasa; dan (2) 
Investasi khusus, disebut juga muḍārabah muqayyadah, di mana sumber dana khusus dengan penyaluran yang khusus dengan syarat-syarat yang telah ditetapkan oleh șaḥib al-māl (Antonio 2001).

\section{Deposito Muḍārabah}

Pengertian deposito menurut Undang-Undang No. 10 Tahun 1998 tentang Perbankan, dinyatakan bahwa simpanan yang penarikannya hanya dapat dilakukan pada waktu tertentu berdasarkan perjanjian nasabah penyimpan dengan bank. Deposito syariah adalah deposito yang dijalankan berdasarkan prinsip syariah (Karim 2009). Dalam hal ini, Dewan Syariah Nasional MUI telah mengeluarkan fatwa yang menyatakan bahwa deposito yang dibenarkan adalah deposito yang berdasarkan prinsip muḍ̄rabah. Bank bertindak sebagai muḍārib (pengelola dana) sedangkan nasabah bertindak sebagai șahib al-māl (pemilik dana). Dengan demikian, bank syariah dalam kapasitasnya sebagai muḍārib memiliki sifat sebagai wali amanah (trustee), yakni harus berhati-hati atau bijaksana serta beritikad baik dan bertanggung jawab atas segala sesuatu yang timbul akibat kesalahan atau kelalaiannya. Bank syariah juga bertindak sebagai kuasa dari usaha bisnis pemilik dana yang diharapkan dapat memperoleh keuntungan seoptimal mungkin tanpa melanggar berbagai aturan syariah.

Dari hasil pengelolaan dana muḍārabah, bank syariah akan membagihasilkan kepada pemilik dana sesuai dengan nisbah yang telah disepakati dan dituangkan dalam akad pembukaan rekening. Dalam mengelola dana tersebut, bank tidak bertanggung jawab terhadap kerugian yang bukan disebabkan oleh kelalaiannya. Namun, apabila yang terjadi adalah mismanagement (salah urus), bank bertanggung jawab penuh terhadap kerugian tersebut. 


\section{Produk Domestik Bruto (PDB)}

Gross Domestic Product (GDP) atau Produk Domestik Bruto (PDB) adalah nilai barang dan jasa yang diproduksi di dalam negara yang bersangkutan untuk kurun waktu tertentu. Interpretasi dari pernyataan tersebut mengindikasikan bahwa yang akan dihitung dalam kategori GDP adalah produk atau output yang berupa barang dan jasa dalam suatu perekonomian yang diproduksi oleh input atau faktor-faktor produksi yang dimiliki oleh warga negara yang bersangkutan maupun oleh warga negara asing yang tinggal secara geografis di negara itu (Sunyoto 2014). Manfaat perhitungan PDB (Produk Domestik Bruto) menurut Rahardja dan Manurung adalah sebagai berikut (Prathama Rahardja and Mandala Manurung 2008): (1) Menganalisis tingkat kemakmuran suatu negara; (2) Menganalisis tingkat kesejahteraan sosial suatu masyarakat; (3) Mencerminkan tingkat produktivitas suatu negara; dan (4) Penghitungan PDB dan kegiatan-kegiatan ekonomi tak tercatat (Underground Economy).

\section{Bagi Hasil}

Bagi hasil adalah suatu sistem pengolahan dana dalam perekonomian Islam, yakni pembagian hasil usaha antara pemilik modal (shahibul maal) dan pengelola (muḍārib) (Antonio 2001). Prinsip bagi hasil di Indonesia diterapkan dengan dua metode, yaitu profit sharing dan revenue sharing. Profit sharing adalah perhitungan bagi hasil didasarkan kepada hasil net dari total pendapatan setelah dikurangi dengan biaya-biaya yang dikeluarkan untuk memperoleh pendapatan tersebut (Muhamad 2014). Sementara pada revenue sharing (bagi pendapatan), perhitungan bagi hasil didasarkan pada pendapatan usaha tanpa dikurangi beban maupun biaya-biaya usaha (Ifham 2015). 


\section{Jumlah Kantor Bank Syariah}

Office channeling dapat diartikan sebagai kantor yang berfungsi menyalurkan atau meneruskan layanan syariah kepada masyarakat. Jumlah kantor bank syariah menjadi salah satu faktor yang mendukung proses pelayanan antara pihak bank dengan nasabah. Semakin banyak kantor didirikan, semakin mudah pula bagi masyarakat untuk memilih produkproduk bank syariah. Lokasi kantor yang mudah dijangkau menjadi faktor pendukung minat masyarakat dalam memilih bank syariah untuk menginvestasikan dananya. Menurut Arif (Arif 2010), dalam praktiknya jenisjenis kantor bank terdiri dari kantor pusat, kantor wilayah, kantor cabang penuh/utama, kantor cabang pembantu dan kantor kas.

Hipotesis

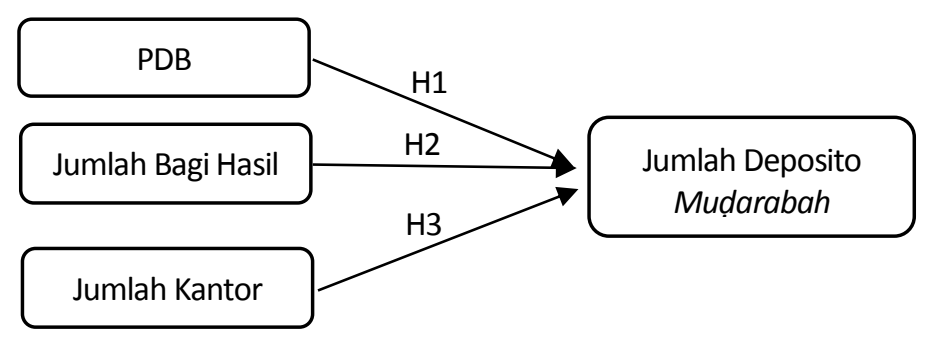

Sumber : olahan peneliti

Hipotesis-hipotesis yang akan diuji dalam penelitian ini berdasarkan atas latar belakang, rumusan masalah, telaah pustaka dan landasan teori bahwa variabel dependen jumlah deposito muḍārabah dipengaruhi oleh variabel independen PDB, jumlah bagi hasil dan jumlah kantor adalah sebagai berikut:

\section{Pengaruh PDB terhadap Jumlah Deposito Muḍārabah}

Teori yang dikemukakan oleh Keynes menyatakan bahwa tabungan merupakan sisa pendapatan yang tidak dibelanjakan oleh konsumen. Sehingga semakin tinggi pendapatan nasional maka semakin tinggi tabungan masyarakat (Sukirno 2005). PDB sebagai salah satu indikator tingkat 
pendapatan masyarakat ikut memengaruhi jumlah deposito muḍārabah bank syariah. Dengan demikian, hipotesis dalam penelitian ini adalah:

$\mathrm{H}_{1}$ : Produk Domestik Bruto (PDB) berpengaruh terhadap jumlah deposito muḍarabah

\section{Pengaruh Jumlah Bagi Hasil terhadap Jumlah Deposito Muḍārabah}

Masyarakat dalam menempatkan dananya di bank syariah masih dipengaruhi oleh motif untuk mencari keutungan melalui tingkat return yang ditawarkan, sehingga faktor bagi hasil sebagai return dari investasi yang dilakukan menjadi faktor yang sangat penting bagi masyarakat sebelum menempatkan dananya. Semakin tinggi jumlah bagi hasil yang ditawarkan maka semakin tinggi pula minat masyarakat dalam menempatkan dananya pada produk deposito muḍarrabah bank syariah. Dengan demikian, hipotesis dalam penelitian ini adalah:

$\mathrm{H}_{2}$ : Jumlah bagi hasil berpengaruh terhadap jumlah deposito mudarabah.

\section{Pengaruh Jumlah Kantor terhadap Jumlah Deposito Muḍārabah}

Faktor pelayanan bank syariah dalam bentuk jumlah kantor juga memengaruhi besarnya jumlah deposito muḍārabah. Semakin banyaknya jumlah kantor bank syariah, maka akan memudahkan masyarakat menempatkan dananya pada bank syariah terutama dalam produk deposito muḍārabah. Dengan demikian, hipotesis dalam penelitian ini adalah:

$\mathrm{H}_{3}$ : Jumlah kantor berpengaruh terhadap jumlah deposito muḍarabah.

\section{Metode Penelitian}

\section{Metode Penentuan Sampel}

Teknik pemilihan sampel dalam penelitian ini adalah dengan menggunakan Non Probability Sampling, yaitu semua elemen dalam populasi tidak memiliki kesempatan yang sama untuk dipilih menjadi sampel. Populasi 
dalam penelitian ini adalah semua Bank Umum Syariah (BUS) di Indonesia. Sedangkan sampel yang digunakan adalah Bank Umum Syariah yang sesuai dengan kriteria yang telah ditentukan. Berdasarkan kriteria yang telah ditentukan, diperoleh sampel dalam penelitian ini, yaitu enam Bank Umum Syariah di Indonesia, di antaranya Bank Muamalat Indonesia, Bank Syariah Mandiri, BNI Syariah, BRI Syariah, Bank Bukopin Syariah dan BCA Syariah. Alasan memilih objek penelitian ini dikarenakan keenam bank tersebut, secara konsisten mengalami tingkat efisiensi $100 \%$ selama tiga tahun berturut-turut.

\section{Analisis Data}

Metode analisis data yang digunakan untuk mengetahui pengaruh PDB, jumlah bagi hasil dan jumlah kantor terhadap jumlah deposito muḍārabah bank syariah dalam penelitian ini adalah analisis regresi data panel. Data panel merupakan data yang merupakan gabungan antara data runtut waktu (time series) dan data silang waktu (cross section) (Ghozali 2013).

\section{Model Regresi Data Panel}

Penelitian ini menggunakan analisis regresi dengan data panel. Analisis regresi dengan data panel digunakan sebagai alat untuk mengukur pengaruh variabel independen $(\mathrm{X})$ terhadap variabel dependen $(\mathrm{Y})$. Persamaan dalam penelitian ini adalah sebagai berikut:

$J D_{t i}=\beta_{0 i}+\beta_{1} P B_{t i}+\beta_{2} J B H_{t i}+\beta_{3} J K_{t i}+e_{t i}$

Keterangan:

$\mathrm{JD}_{\mathrm{ti}} \quad=$ jumlah deposito mudarabah

$\beta_{0 \mathrm{i}} \quad=$ konstanta model regresi pada unit observasi ke- $\mathrm{i}$

$\beta_{1}, \beta_{2}, \beta_{3}, \beta_{4}=$ koefisien variabel independen

PDB = produk domestik bruto

JBH = jumlah bagi hasil 


$$
\begin{array}{ll}
\mathrm{JK} & =\text { jumlah kantor } \\
\mathrm{e}_{\mathrm{ti}} & =\text { koefisien eror }
\end{array}
$$

\section{Hasil dan Pembahasan}

\section{Uji Asumsi Klasik}

\section{Uji Normalitas}

Uji normalitas dimaksudkan untuk menguji apakah nilai residual yang telah distandarisasi pada model regresi berdistribusi normal atau tidak. Nilai residul dikatakan berdistribusi normal jika nilai residual terstandarisasi tersebut sebagian besar mendekati nilai rata-ratanya (Ghozali 2013). Pengujian normalitas dalam penelitian ini menggunakan uji Jarque-Bera (JB) dengan melihat nilai probability. Jika nilai probability lebih besar dari tingkat signifikansi $\alpha=0.05$ atau 5\% maka data dalam penelitian ini terdistribusi normal. Sebaliknya, jika nilai probability lebih kecil dari tingkat signifikansi $\alpha$ $=0.05$ atau 5\% maka data dalam penelitian ini tidak terdistribusi normal.

Tabel 3. Hasil Uji Normalitas

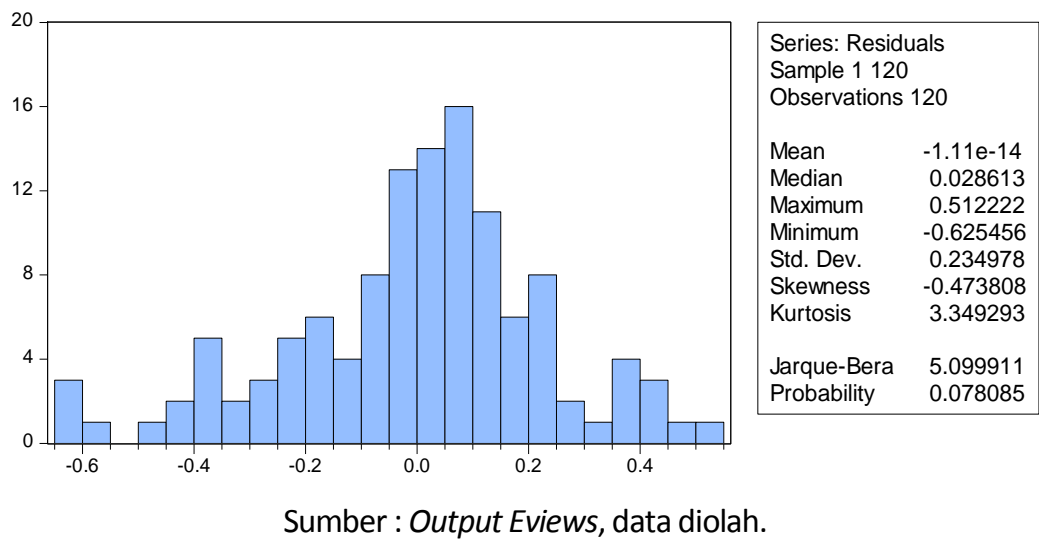

Berdasarkan histogram uji normalitas di atas dapat diketahui bahwa probability JB adalah 0.078085 . Nilai probability lebih besar dari tingkat 
signifikansi $\alpha=0.05$ atau 5\%. Sehingga dapat disimpulkan bahwa data dalam penelitian ini berdistribusi normal.

\section{Uji Multikolinieritas}

Uji multikolinieritas bertujuan untuk menguji apakah dalam model regresi yang terbentuk ada korelasi yang tinggi atau sempurna di antara variabel bebas atau tidak. Jika dalam model regresi yang terbentuk terdapat korelasi yang tinggi atau sempurna di antara variabel bebas maka model regresi tersebut dinyatakan mengandung gejala multikolinier (Suliyanto 2011). Gejala multikolinieritas dilihat dari nilai Tolerance dan Variance Inflation Factor (VIF). Tolerance mengukur variabilitas variabel independen lainnya. Jadi nilai tolerance yang rendah sama dengan nilai VIF tinggi karena $\mathrm{VIF}=1 /$ tolerance . Nilai cutoff yang umum dipakai untuk menunjukkan adanya multikolinierias adalah nilai tolerance $<0.10$ atau sama dengan $\mathrm{VIF}>10$. Sebagai misal nilai tolerance $=0.10$ sama dengan tingkat kolinieritas 0.90 .

Tabel 4. Hasil Uji Multikolinieritas

\begin{tabular}{cccc}
\hline & PDB & JBH & JK \\
\hline PDB & 1.000000 & 0.223918 & 0.150872 \\
JBH & 0.223918 & 1.000000 & 0.838768 \\
JK & 0.150872 & 0.838768 & 1.000000 \\
\hline
\end{tabular}

Sumber : Output Eviews, data diolah.

Berdasarkan tabel di atas, dapat diketahui bahwa hubungan antar variabel independen (PDB, jumlah bagi hasil dan jumlah kantor) tidak ada yang menunjukkan nilai korelasi diatas 0.9. Nilai korelasi tertinggi sebesar 0.838768 yaitu antara jumlah bagi hasil dengan jumlah kantor. Karena $0.838768<0.9$ maka dapat disimpulkan bahwa dalam model tidak terjadi gejala multikolinieritas. 


\section{Uji Heteroskedastisitas}

Heteroskedastisitas berarti ada varian variabel pada model regresi yang tidak sama (konstan). Sebaliknya, jika varian variabel pada model regresi memiliki nilai yang sama (konstan) maka disebut dengan homokedastisitas (Suliyanto 2011). Dalam penelitian ini, uji statistik untuk mendeteksi ada tidaknya heteroskedastisitas dilakukan dengan UJi White dengan melihat nilai probability Chi-square. Jika nilai probability Chi-square lebih besar dari tingkat signifikansi $\alpha=0.05$ atau 5\% maka data dalam penelitian ini tidak terkena heteroskedastisitas. Sebaliknya jika nilai probability Chi-square lebih kecil dari tingkat signifikansi $\alpha=0.05$ atau 5\% maka data dalam penelitian ini terkena heteroskedastisitas.

Tabel 5. Hasil Uji Heteroskedastisitas

\section{Heteroskedasticity Test: White}

\begin{tabular}{llll}
\hline F-statistic & 1.473202 & Prob. F(3,116) & 0.2255 \\
Obs*R-squared & 4.404206 & Prob. Chi-Square(3) & 0.2210 \\
Scaled explained SS & 4.834241 & Prob. Chi-Square(3) & 0.1843 \\
\hline
\end{tabular}

Sumber : Output Eviews, data diolah.

Berdasarkan tabel hasil uji white dapat diketahui bahwa nilai probability chi-square sebesar 0.2210 . Nilai probability chi-square lebih besar dari 0.05 (0.2210> 0.05) sehingga dapat disimpulkan bahwa tidak terjadi gejala heteroskedastisitas dalam model penelitian.

\section{Uji Autokorelasi}

Autokorelasi adalah adanya korelasi antara variabel itu sendiri, pada pengamatan yang berbeda waktu atau individu. Umumnya kasus autokorelasi banyak terjadi pada data time series. Untuk mendeteksi adanya autokorelasi dalam penelitian ini menggunakan Uji Lagrange Multiplier (LM Test) atau uji Breusch-Godfrey dengan melihat nilai probability chi-square. Jika nilai probability chi-square lebih besar dari tingkat signifikansi $\alpha=0.05$ atau $5 \%$ 
maka data dalam penelitian ini tidak terkena autokorelasi. Sebaliknya jika nilai probability Chi-square lebih kecil dari tingkat signifikansi $\alpha=0.05$ atau 5\% maka data dalam penelitian ini terkena autokorelasi.

Tabel 6. Hasil Uji Autokorelasi Sebelum Diferensiasi

\section{Breusch-Godfrey Serial Correlation LM Test:}

\begin{tabular}{llll}
\hline F-statistic & 83.85575 & Prob. F(2,114) & 0.0000 \\
Obs*R-squared & 71.43968 & Prob. Chi-Square(2) & 0.0000 \\
\hline
\end{tabular}

Sumber: Output Eviews, data diolah.

Berdasarkan tabel hasil uji autokorelasi di atas dapat diketahui bahwa nilai probability chi-square kurang dari $0.05(0.0000<0.05)$ sehingga dapat disimpulkan bahwa dalam model penelitian terdapat masalah autokorelasi. Untuk mengoreksi masalah autokorelasi dalam model penelitian dapat dilakukan differensiasi pada variabel yaitu $\mathrm{D}(\mathrm{Ln})$ hingga tidak terjadi masalah autokorelasi dalam model penelitian. Berikut adalah hasil uji autokorelasi setelah dilakukan differensiasi.

Tabel 7. Hasil Uji Autokorelasi Setelah Diferensiasi

Breusch-Godfrey Serial Correlation LM Test:

\begin{tabular}{llll}
\hline F-statistic & 1.213156 & Prob. F(2,113) & 0.3011 \\
Obs*R-squared & 2.501432 & Prob. Chi-Square(2) & 0.2863 \\
\hline
\end{tabular}

Sumber : Output Eviews, data diolah.

Tabel di atas menunjukkan bahwa setelah dilakukan differensiasi, nilai probability chi-square adalah 0.2863 . Nilai ini lebih besar dari derajat kesalahan $\alpha=5 \%$ (0.05). Maka dapat disimpulkan bahwa dalam model penelitian ini tidak terdapat masalah autokorelasi. 


\section{Uji Hipotesis}

Penelitian ini menggunakan analisis regresi data panel untuk menguji beberapa hipotesa yang diajukan. Ringkasan hasil pengujian regresi data panel tampak pada tabel sebagai berikut:

Tabel 8. Hasil Uji Model Regresi Data Panel

\begin{tabular}{ccccc}
\hline Variable & Coefficient & Std. Error & t-Statistic & Prob. \\
\hline C & -18.32819 & 4.443782 & -4.124457 & 0.0001 \\
PDB & 1.020510 & 0.140756 & 7.250194 & 0.0000 \\
JBH & 0.439503 & 0.039123 & 11.23397 & 0.0000 \\
JK & 0.241622 & 0.041941 & 5.761057 & 0.0000 \\
\hline
\end{tabular}

Sumber: ouput Eviews, data diolah

\section{a. Pengaruh PDB terhadap Jumlah Deposito Muḍārabah}

Hipotesa 1 menyatakan bahwa PDB berpengaruh terhadap jumlah deposito muḍ̄rabah. Setelah melakukan pengujian hipotesis menggunakan analisis regresi data panel, diketahui bahwa tingkat signifikan variabel PDB yaitu 0.0000 , lebih kecil dari 0.05 sehingga $\mathrm{H}_{1}$ dapat diterima. Hasil ini mengindikasikan bahwa PDB sebagai indikator pendapatan masyarakat memengaruhi jumlah deposito muḍārabah bank syariah. Pendapatan yang diperoleh oleh masyarakat setelah digunakan untuk memenuhi kebutuhan sehari-harinya, maka sisanya akan diinvestasikan ke dalam berbagai bentuk investasi, salah satunya deposito muḍārabah. Pola menabung yang dilakukan oleh masyarakat sangat tergantung pada pendapatan yang dimilikinya. Jadi semakin besar pendapatan masyarakat maka semakin besar pula kemampuannya untuk menabung.

Hasil penelitian ini mendukung penelitian yang dilakukan oleh Zainal, dkk (Zainal, Yusof, and Jusoff 2009), Yoviasari (Yoviasari 2013), dan Hilman 
(Hilman 2016) yang menyatakan bahwa PDB berpengaruh signifikan terhadap deposito muḍārabah bank syariah karena kemampuan masyarakat untuk menabung atau melakukan investasi sangat tergantung pada pendapatan yang dimiliki.

\section{b. Pengaruh Jumlah Bagi Hasil terhadap Jumlah Deposito Muḍārabah}

Hipotesa 2 menyatakan bahwa jumlah bagi hasil berpengaruh terhadap jumlah deposito mudārabah. Setelah melakukan pengujian hipotesis menggunakan analisis regresi data panel, diketahui bahwa tingkat signifikan variabel jumlah bagi hasil yaitu 0.0000 , lebih kecil dari 0.05 sehingga $\mathrm{H}_{2}$ dapat diterima. Hasil ini mengindikasikan bahwa dalam menginvestasikan dananya, masyarakat masih dipengaruhi oleh motif mencari keuntungan. Masyarakat akan memilih untuk menempatkan dananya dalam bentuk investasi yang menghasilkan return yang tinggi. Sehingga bagi hasil sebagai return atas investasi yang dilakukan pada produk deposito memengaruhi jumlah deposito mudārabah. Apabila bagi hasil yang diberikan meningkat, maka keinginan masyarakat untuk menabung juga akan mengalami peningkatan.

Hasil penelitian ini mendukung penelitian yang dilakukan oleh Rachmawati dan Eki (2004), Kassim (2009), Yudho (Yudho 2010) dan Suratman (Suratman 2013) yang menyatakan bahwa bagi hasil berpengaruh signifikan terhadap deposito mudārabah karena semakin besar jumlah bagi hasil yang diberikan maka semakin besar pula jumlah deposito muḍārabah pada bank syariah.

\section{c. Pengaruh Jumlah Kantor terhadap Jumlah Deposito Muḍārabah}

Hipotesa 3 menyatakan bahwa jumlah kantor berpengaruh terhadap jumlah deposito mudārabah. Setelah melakukan pengujian hipotesis menggunakan analisis regresi data panel, diketahui bahwa tingkat signifikan variabel jumlah kantor yaitu 0.0000 , lebih kecil dari 0.05 sehingga $\mathrm{H}_{3}$ dapat 
diterima. Hasil ini mengindikasikan bahwa jumlah kantor sebagai bentuk pelayanan bank syariah kepada masyarakat ikut memengaruhi jumlah deposito muḍārabah. Ketika bank syariah memperluas jaringannya dengan menambah jumlah kantor, maka kesempatan bank syariah untuk menghimpun dana juga semakin besar. Sehingga semakin banyak jaringan kantor yang didirikan oleh bank syariah, maka semakin besar kesempatan bank syariah untuk dapat meningkatkan jumlah deposito muḍārabah.

Hasil penelitian ini mendukung penelitian yang dilakukan oleh Yudho (Yudho 2010) dan Marifat (Marifat 2016) yang menyatakan bahwa jumlah kantor berpengaruh terhadap deposito muḍārabah bank syariah karena semakin banyak jumlah kantor yang didirikan oleh bank syariah maka semakin banyak pula jumlah deposito muḍ̄rabah.

\section{Simpulan}

Berdasarkan hasil penelitian regresi data panel yang telah dilakukan pada pembahasan sebelumnya, maka dapat ditarik kesimpulan bahwa PDB, jumlah bagi hasil dan jumlah kantor memengaruhi jumlah deposito muḍārabah bank syariah di Indonesia. Semakin tinggi PDB sebagai indikator pendapatan masyarakat, maka semakin tinggi jumlah bagi hasil yang diberikan oleh bank syariah. Semakin banyak jumlah kantor yang didirikan, maka semakin tinggi pula jumlah deposito muḍārabah bank syariah. Berikut adalah temuan hasil penelitian ini :

1. Variabel PDB memiliki tingkat signifikan 0.0000, karena tingkat signifikan lebih kecil dari 0.05 maka secara parsial variabel independen PDB berpengaruh secara signifikan terhadap variabel dependen yaitu jumlah deposito mudārabah. PDB memiliki arah koefisien positif, jadi semakin besar PDB maka semakin besar juga jumlah deposito muḍārabah bank syariah.

2. Variabel jumlah bagi hasil memiliki tingkat signifikan 0.0000 , karena tingkat signifikan lebih kecil dari 0.05 maka secara parsial variabel 
independen jumlah bagi hasil berpengaruh secara signifikan terhadap variabel dependen yaitu jumlah deposito mudārabah. Jumlah bagi hasil memiliki arah koefisien positif, jadi semakin besar jumlah bagi hasil maka semakin besar juga jumlah deposito muḍārabah bank syariah.

3. Variabel jumlah kantor memiliki tingkat signifikan 0.0000, karena tingkat signifikan lebih kecil dari 0.05 maka secara parsial variabel independen jumlah kantor berpengaruh secara signifikan terhadap variabel dependen yaitu jumlah deposito muḍārabah. Jumlah kantor memiliki arah koefisien positif, jadi semakin besar jumlah kantor maka semakin besar juga jumlah deposito muḍārabah bank syariah.

Dari hasil penelitian ini ada beberapa saran yang penulis kemukakan, antara lain:

1. Bagi bank syariah, karena peningkatan deposito muḍārabah tidak terlepas dari faktor internal maupun faktor eksternl, maka beberapa hal yang harus dilakukan antara lain penguatan modal, memiliki antisipasi terhadap makroekonomi, adanya sistem manajemen yang baik serta sosialisasi terhadap masyarakat luas terutama tentang produk bank syariah.

2. Bagi nasabah, dengan adanya hasil penelitian ini diharapkan dapat menjadi pedoman pengambilan keputusan dalam berinvestasi agar memberikan tingkat keuntungan yang sesuai dengan harapan investor.

3. Bagi akademisi, penelitian ini ini diharapkan dapat menjadi salah satu tambahan referensi mengenai perbankan syariah. Untuk peneliti selanjutnya sebaiknya memperbanyak jumlah variabel seperti: FDR, ROA, ROE, kurs, ukuran bank dan lainnya. 


\section{Daftar Pustaka}

Antonio, Muhammad Syafii. 2001. Bank Syariah: Dari Teori Ke Praktik. Jakarta: Gema Insani Press.

Arif, Nur Rianto. 2010. Dasar-Dasar Pemasaran Bank Syariah. Bandung: Alfabeta.

Arifin, Zainul. 2009. Dasar-Dasar Manajemen Bank Syariah. Tangerang: Azkia Publisher.

Ghozali, Imam. 2013. Analisis Multivariate Dan Ekonometrika Teori, Konsep Dan Aplikasi Dengan Eviews 8. Semarang: Badan Penerbit Universitas Diponegoro.

Hilman, Iim. 2016. "The Factors Affecting Mudharabah Deposits of Sharia Banking in Indonesia." International Journal of Business and Management Invention 5 (8): 56-66. http://www.ijbmi.org/v5i8(version3).html.

Ifham, Ahmad. 2015. Ini Lho Bank Syariah! Memahami Bank Syariah Dengan Mudah. Jakarta: PT Gramedia Pustaka Utama.

Karim, Adiwarman. 2009. Bank Islam: Analisis Fiqih Dan Keuangan. Jakarta: Rajawali Pers.

Kasri, Rahmatina A. and Salina Hj. Kassim. 2009. "Empirical Determinants of Saving in the Islamic Banks: Evidence from Indonesia." Journal of King Abdulaziz University: Islamic Economics 22 (2): 181-201. http://iei.kau.edu.sa/Pages-VOL-22-02.aspx.

Marifat, Ifat. 2016. “Analisis Pengaruh Tingkat Bagi Hasil Deposito Muḍarabah, Jumlah Kantor Layanan, Inflasi dan PDB terhadap Jumlah Deposito Muḍarabah pada Bank Umum Syariah (BUS) di Indonesia." Skripsi. UIN Syarif Hidayatullah Jakarta.

Muhamad. 2014. Manajemen Keuangan Syari'ah: Analisis Fiqh \& Keuangan. Yogyakarta: UPP STIM YKPN.

Prathama Rahardja and Mandala Manurung. 2008. Teori Ekonomi Makro. Edisi Keempat. Jakarta: Lembaga Penerbit Fakultas Ekonomi Indonesia.

Sadi, Muhamad. 2015. Konsep Hukum Perbankan Syariah. Malang: Setara Press.

Sudarsono, Heri. 2009. “Dampak Krisis Keuangan Global terhadap Perbankan di Indonesia: Perbandingan antara Bank Konvensional dan Bank 
Syariah." La_Riba 3 (1): 12-23. https://doi.org/10.20885/lariba. vol3.iss1.art2.

Suliyanto. 2011. Ekonometrika Terapan: Teori Dan Aplikasi Dengan SPSS. Yogyakarta: Andi Offset.

Sunyoto, Erni Umi Hasanah, Danang. 2014. Pengantar Ilmu Ekonomi Makro (Teori \& Soal). Yogyakarta: CAPS.

Suratman. 2013. "Pengaruh Jumlah Bagi Hasil Deposito Mudarabah, Tingkat Imbalan SBIS, Suku Bunga Simpanan Berjangka 1 Bulan, dan Inflasi terhadap Jumlah Deposito Muḍarabah." Skripsi. UIN Syarif Hidayatullah Jakarta.

Yoviasari, Fiska. 2013. "Pengaruh Nisbah Bagi Hasil, Inflasi dan Produk Domestik Bruto terhadap Deposito Muḍarabah Bank Syariah di Indonesia." Skripsi. UIN Maulana Malik Ibrahim Malang.

Yudho, Aryanto. 2010. "Analisis Faktor-Faktor yang Mempengaruhi Deposito Mudharabah Bank Syariah di Indonesia Tahun 2002-2009." Tesis. Universitas Indonesia.

Zainal, Noor Saliza, Zulkafli Mohd. Yusof, and Kamaruzaman Jusoff. 2009. "Influence of Economic Factors on Performance of Investment and Mudharabah Accounts in Maybank, Malaysia." International Journal of Economics and Finance 1 (2): 221. https://doi.org/10.5539/ ijef.v1n2p221. 
